\title{
Association between terbinafine hydrochloride and sperm DNA fragmentation - case report
}

\author{
Andressa Moreira Giusti ${ }^{1}$, Gabriela Reif ${ }^{1}$, Danilo Modafaris Araújo ${ }^{1}$, Alfred Paul Senn², Vera Lucia Lângaro Amaral ${ }^{1}$ \\ ${ }^{1}$ Universidade do Vale do Itajaí, Itajaí - SC, 88302-901, Brazil \\ 2University of Geneva, Department of Genetic Medicine \& Development, Geneva, Switzerland
}

\begin{abstract}
Objective: To present the case of a man with normozoospermia and a high level of fragmented spermatozoa, which origin seems to be associated with long-term treatment with terbinafine hydrochloride.

Case description: A 20-year-old male healthy patient, with no history of disease and addictions, used an antifungal (terbinafine hydrochloride) for one year to treat a toenail. During this treatment, he participated in a study to evaluate a method of sperm DNA fragmentation analysis. He had $99 \%$ fragmented sperm, primarily attributed to prolonged abstinence. The samples that were analyzed later indicated that the high fragmentation could be associated with the antifungal treatment and that with a 2-day abstinence and absence of treatment the fragmentation rate was again comparable with that of fertile men $(15 \%)$.

Conclusion: Terbinafine hydrochloride is likely to cause problems in male fertility, mainly affecting DNA sperm integrity. Further studies are needed to confirm this observation and to determine at what level of the genitourinary tract the alteration of DNA occurs.
\end{abstract}

Keywords: sperm analysis, human, terbinafine, antifungal, case report, DNA fragmentation

\section{INTRODUCTION}

Terbinafine hydrochloride is a drug indicated in the treatment of several fungal infections of the skin and nails (AbdelSamie et al., 2016; Kanakapura \& Penmatsa, 2016; Kuminek et al., 2013). This drug inhibits the squalene-epoxidase enzyme, responsible for the biosynthesis of ergosterol, an essential sterol of the plasma membrane of fungi with functions like those of cholesterol in animal cells. The decrease of ergosterol modifies the membrane permeability, causing lysis and cell death (Petranyi et al., 1984; Stütz \& Petranyi, 1984).

Terbinafine hydrochloride is part of the list of essential drugs of the World Health Organization (WHO, 2019) and its package insert indicates possible side effects, but it does not provide relevant information on fertility in animals or humans (CRISTALIA - Produtos Químicos Farmacêuticos Ltda., 2017). However, some studies suggest that certain antifungals can impact spermatogenesis (Millsop et al., 2013; Pasqualotto, 2007; Semet et al., 2017; Stedile, 2014).

To evaluate male fertility, a set of tests are performed, among which sperm analysis is the most important, and it includes evaluations of spermatozoa concentration, motility, vitality, and morphology (WHO, 2010). The correlations between the values of these parameters and the occurrence of pregnancy are complex and the diagnosis of the presence of a "male factor" in infertility requires the evaluation of a specialist (Cooper et al., 2010; Guzick et al., 2001; Pasqualotto, 2007; Pasqualotto et al., 2005).
Among the factors involved in successful fertilization and embryonic development, sperm DNA fragmentation is associated with increased miscarriage (Gosálvez et al., 2013; McQueen et al., 2019; Zhang et al., 2015), but there is still no clinically recognized threshold for choosing the best medically assisted procreation treatment (Vandekerckhove et al., 2016; Zhang et al., 2015). The causes of DNA fragmentation are associated with several factors such as protamine/chromatin deficiency, failure to repair breaks in DNA strips, and exposure to reactive oxygen species (ROS) during sperm transport through the genitourinary tract (Chohan et al., 2006; Evenson, 2016; Gosálvez et al., 2011; Practice Committee of the American Society for Reproductive Medicine, 2013; Rex et al., 2017; Sakkas \& Alvarez, 2010; Zini \& Libman, 2006). Thus, in recent years, spermatic DNA fragmentation testing has become an important biomarker for male infertility (Ribas-Maynou et al., 2013).

The objective of this report is to present a case of a man with normozoospermia and a high level of fragmented spermatozoa, whose origin appears to be associated with antifungal treatment.

\section{CASE DESCRIPTION}

This is a male, 20-year-old healthy patient, with no history of relevant diseases and no addictions. He reported suffering an injury during a sports practice at the end of 2016 , followed by the nail loss of the left foot big toe. After anamnesis and evaluation of the lesion, performed by a dermatologist in 2018 , the patient started oral treatment with terbinafine hydrochloride ( $500 \mathrm{mg} /$ day, for 1 year). During the treatment, the patient did not have complications or side effects caused by the medication and did not use any other medication.

In May 2019, the patient initiated his participation, voluntarily, in an academic study of sperm DNA fragmentation analysis, approved by the Research Ethics Committee. Two seminal samples were analyzed on May 9, 2019, with an interval of one hour between collections. Both samples were classified as teratozoospermic (WHO, 2010) and had sperm DNA fragmentation indexes (DFI) of $99 \%$ and $100 \%$, respectively. On May 20, 2019, eleven days after the first evaluation, a new analysis was performed and the DFI was $84 \%$.

To determine if the high fragmentation rate could be due to the antifungal treatment, the patient decided to voluntarily suspend it, since the toe treatment had been successful. A new semen analysis was performed on September 10, 2019 and showed a DFI of $15 \%$ without major changes of the sperm parameters. On December 4, 2019, after six months and fourteen days without the use of terbinafine hydrochloride, a new analysis was performed. He was then classified as normozoospermic and presented a DFI of $44 \%$. It is worth mentioning that, in the week before the examination, the patient used an antibiotic (Cephalexin $500 \mathrm{mg}, 4$ pills/24h), to treat a skin infection. 
All the data obtained in the sperm tests are presented on Table 1, the halo types (\%) are shown in Figure 1.

\section{METHODS}

Terbinafine hydrochloride $(\mathrm{C} 21 \mathrm{H} 26 \mathrm{CIN})$ was administered orally (2 tablets of $250 \mathrm{mg} / 24 \mathrm{~h}$, Funtyl ${ }^{\circledR}$, Cristália, Itapira-SP, Brazil). The protocol used to detect DNA fragmentation was developed and validated during the execution of a research project and was based on the evaluation of spermatic DNA dispersion after the denaturation of nuclear proteins (Fernández et al., 2003). Briefly, an aliquot of semen $(60 \mu \mathrm{L})$, previously diluted to a concentration of sperm near $20 \times 10^{6} /$ $\mathrm{mL}$ was mixed with $140 \mu \mathrm{L}$ of a $1 \%$ agarose solution (Sigma Aldrich), maintained liquid at a temperature of $90^{\circ} \mathrm{C}$. From this mixture, $30 \mu \mathrm{L}$ was deposited on a microscope slide, pre-treated with a $0.65 \%$ agarose. The sperm mixture was immediately covered with a coverslip $(22 \times 22 \mathrm{~mm})$ and the slide was cooled to $4^{\circ} \mathrm{C}$ for five minutes before careful removal of the coverslip. The area containing the agarose was then treated sequentially with a denaturing solution $(0.08 \mathrm{~N} \mathrm{HCl})$ for $7 \mathrm{~min}$, a lysis solution (Tris- $\mathrm{HCl} 0.4 \mathrm{M}$, Dithiothreitol $0.8 \mathrm{~N}$, SDS $1 \%$, EDTA $50 \mathrm{mM}, \mathrm{pH} 7.5$ ) for $10 \mathrm{~min}$, a solution of lysis 2 (Tris- $\mathrm{HCl} 0.4 \mathrm{M}$, SDS $1 \%, \mathrm{NaCl} 2 \mathrm{M}, \mathrm{pH} 7.5$ ) for $5 \mathrm{~min}$, a phosphate buffer ( $\mathrm{pH} 7.3$, Ingámed, Brazil) for 5 min, alcohol $70 \%$ and $100 \%$ for $2 \mathrm{~min}$, before staining with the Panotic kit (Laborclin, Pinhais-PR, Brazil) without prior fixed treatment.

The slides were studied under a microscope (400x), under bright field illumination. The spermatozoa $(\mathrm{N}=200)$ were classified according to the size of the halos formed around the head (Fernández et al., 2005), as (A) - nucleus with a large halo of DNA dispersion; (B) - nucleus with a medium-sized halo; (C) - nucleus with a small-sized halo; (D) - nucleus without halo; (E) - nucleus without halo and degenerated (Fig 2). The DNA fragmentation index (DFI) was calculated as:

$$
\text { DFI }(\%)=(C+D+E) /(A+B+C+D+E) * 100
$$

Each batch of lysis solutions 1 and 2 produced was validated with a positive control, using semen treated with an iso-osmotic solution containing hydrogen peroxide $(0.5 \%)$ to induce DNA fragmentation through the release of ROS and confirm the absence of halo formation (Cicaré et al., 2016).

\section{DISCUSSION}

The case presented hereby describes a temporal association between long-term oral treatment with terbinafine hydrochloride and the fragmentation of spermatic DNA of a healthy young man. This occurrence, according to our knowledge, has not yet been described in the literature. The interruption of treatment induced a reduction of fragmentation to values normally seen in fertile men (Table 1).

The effects of terbinafine and ketoconazole on the testicular-hypophysis axis in young men were seen after short-term treatment (Nashan et al., 1989). They reported that while the use of ketoconazole showed a decrease in serum testosterone levels and an increase in 17-hydroxyprogesterone levels, the same was not reported with terbinafine, which did not cause any effect on testosterone, as well as on hydroxyprogesterone and LH levels. This may explain the absence of alterations in the sperm parameters, since terbinafine does not seem to interfere directly in spermatogenesis, or indirectly through endocrine hormones. In our case, the long-term treatment with terbinafine showed no effects on spermatogenesis and motility.

In sample 1, we found (Table 1 ) a high concentration of round cells $\left(12.9 \times 10^{6} / \mathrm{mL}\right)$, associated with a high concentration of leukocytes $\left(2.4 \times 10^{6} / \mathrm{mL}\right)$ and a high rate of sperm with fragmented DNA (DFI $=99 \%$ ). The patient also reported a long abstinence (30 days), which led the laboratory to request a second sample an hour later (Sample 2). The fragmentation rate remained very high (DFI=99\%), but the leukocyte count decreased to $0.9 \times 10^{6} / \mathrm{mL}$. The patient was then instructed to maintain an ejaculatory frequency of 2 days and return for a third analysis about 10 days later. In this third sample, the leukocyte concentration decreased to 0 and the total mobility increased to $78 \%$, but the DNA fragmentation remained high (84\%). Only after the prolonged absence of terbinafine hydrochloride administration did the fragmentation rate decrease to $15 \%$ (Sample 4). A final semen collection was performed three months later, almost six months after the antifungal treatment was discontinued (Sample 5). The concentration, motility, and sperm morphology were still within normal limits, but the fragmentation rate had increased again (DFI $=44 \%$ ). It is worth noting that the patient was treating a skin infection in the week before producing Sample 5. Infections are known to cause damage to the sperm DNA, due to increased circulation of ROS, produced by the numerous leukocytes, in addition to the rise in temperature that can occur at times of fever.

Table 1. Data obtained after seminal analysis and spermatic DNA fragmentation test. Samples with an asterisk (*) were collected during the treatment period with Terbinafine Hydrochloride. The leukocytes were differentiated by the peroxidase technique (ENDTZ) (Shekarriz et al., 1995).

\begin{tabular}{|c|c|c|c|c|c|}
\hline \multirow{2}{*}{ Analysis } & \multicolumn{5}{|c|}{ Samples } \\
\hline & $1 *$ & $2 *$ & 3* & 4 & 5 \\
\hline Date of analysis & $09 / 05 / 2019$ & $09 / 05 / 2019$ & $20 / 05 / 2019$ & $10 / 09 / 2019$ & $04 / 12 / 2019$ \\
\hline Abstinence (days) & 30 & 1 hour & 2 & 2 & 2 \\
\hline Volume $(\mathrm{mL})$ & 5.2 & 3.4 & 2.5 & 2.5 & 2.7 \\
\hline Sperm Concentration $\left(10^{6} / \mathrm{mL}\right)$ & 207 & 70 & 95.5 & 55 & 35.7 \\
\hline Round cell concentration $\left(10^{6} / \mathrm{mL}\right)$ & 12.9 & 1.5 & 5 & 1.8 & 2.6 \\
\hline Leukocyte concentration $10^{6} / \mathrm{mL}$ ) & 2.4 & 0.9 & 0 & 0.04 & 0 \\
\hline Progressive and (total) motility (\%) & $53(67)$ & $30(44)$ & $51(78)$ & $45(70)$ & $61(79)$ \\
\hline Vitality (\%) & 70 & 83 & 93 & 95 & 80 \\
\hline Normal morphology (\%) & 3 & 3 & 3 & 4 & 4 \\
\hline DFI (\%) & 99 & 99 & 84 & 15 & 44 \\
\hline
\end{tabular}




\section{Types of halo}

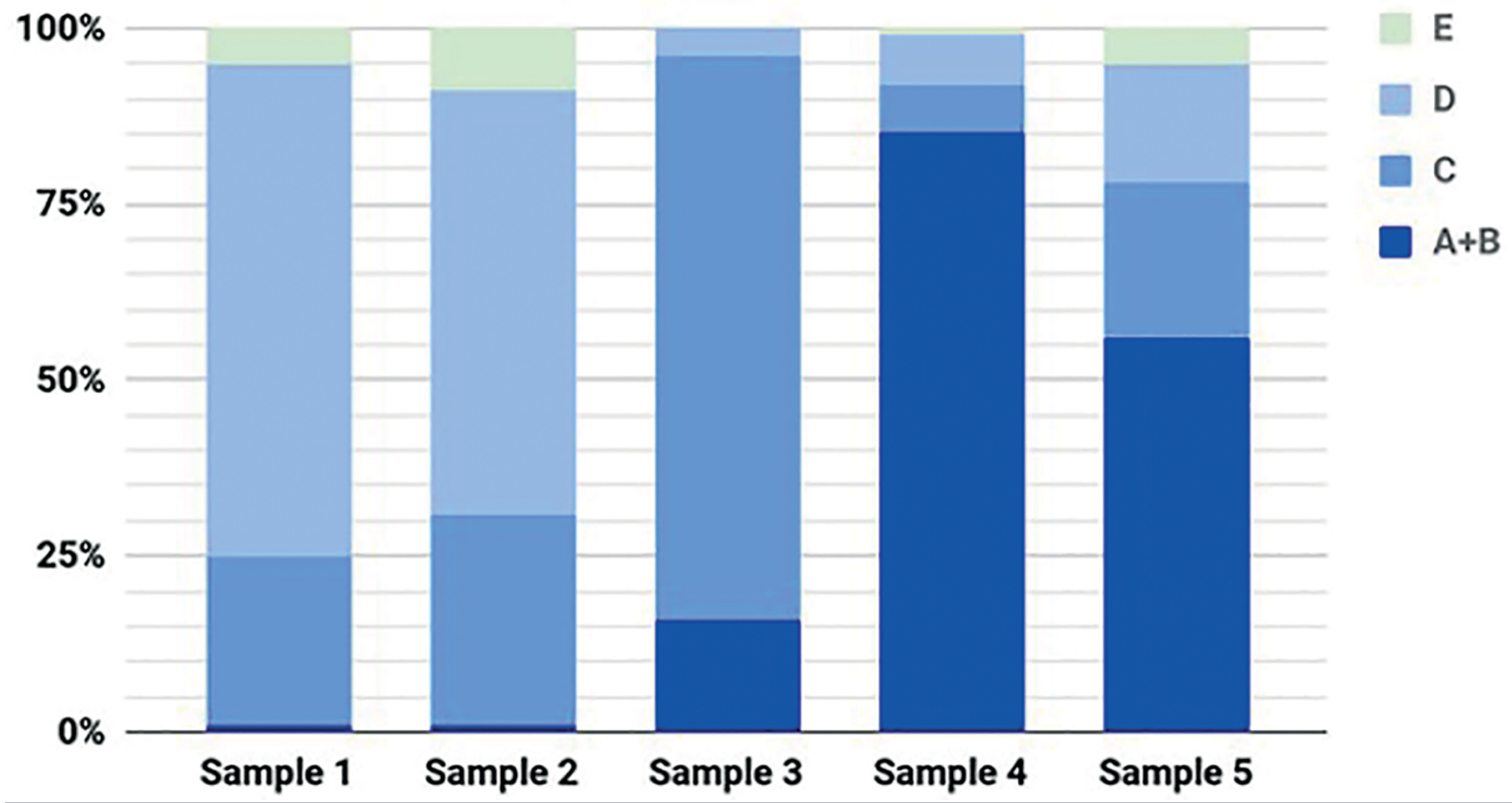

Figure 1. Percentage of the types of halos observed in the samples submitted to the DNA fragmentation test. Types $(A+B)$ : medium to large halo, $(C)$ : small halo, (D): no halo, (E): degenerated nucleus.

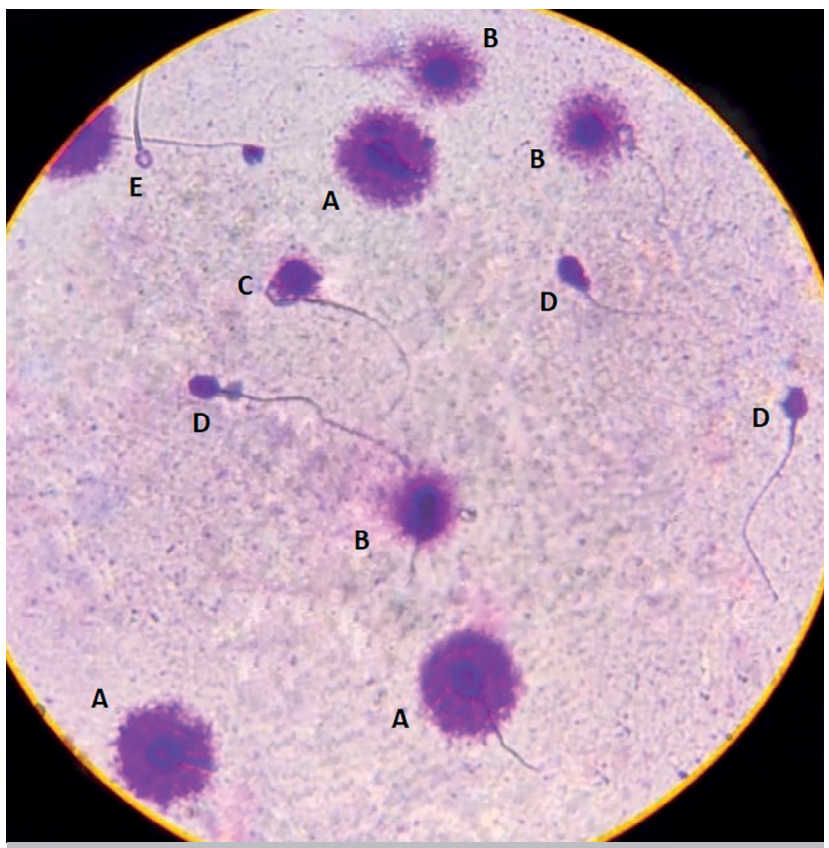

Figure 2. Sperm of the fourth seminal sample with types of halo (A) - nucleus with large halo of dispersion of DNA; (B) - medium size; (C) - small size; (D) - nucleus without halo; (E) - degenerated. (DFI=15\%).

While treatment with terbinafine hydrochloride seems to be associated with very high values of sperm DNA fragmentation, the increase in fragmentation rates after 6 months without treatment seems to indicate that terbinafine is not the only factor involved. We know that ROS are produced under several conditions (Wright et al., 2014), such as advanced age (Nguyen-Powanda \& Robaire, 2020), cancer (Loft \& Poulsen, 1996), varicocele (Abdelbaki et al., 2017), infections, and inflammations in the urogenital tract (Hamdi et al., 2020; Potts \& Pasqualotto, 2003), fever and hyperthermia (Rao et al., 2015), duration of abstinence (Comar et al., 2017), smoking (Loft \& Poulsen, 1996) and exposure to pesticides (Khan et al., 2015; Zamkowska et al., 2018). In our case, it is not clear which of these factors may, besides terbinafine, also have contributed to DNA fragmentation - prolonged abstinence being one of them.

When the abstinence was prolonged, the effects of DNA fragmentation were more visible. Decreasing the abstinence, younger spermatozoids are ejaculated, and are less affected by fragmentation. This is indirect proof that spermatogenesis and testicles are not affected by terbinafine, and the effect of terbinafine may be caused at the level of the epididymis (Okada et al., 2020). Therefore, it is important to investigate further the likely mode of action of terbinafine on spermatozoa and DNA fragmentation. The first hypothesis would be that it exerts a direct effect, penetrating the spermatozoa and affecting the DNA; the second hypothesis is about the indirect effect, in which terbinafine causes an effect on other cells that will cause the fragmentation, releasing ROS, for example.

The case reported hereby should serve as a warning to healthcare professionals, both when prescribing longterm terbinafine treatment and when initiating medically assisted procedures, especially since no sperm parameters seem to be affected by this molecule. Likely, the direct or indirect effect of terbinafine on sperm DNA fragmentation will only be visible during pregnancy, resulting in spontaneous abortion

\section{CONCLUSION}

We report an association between terbinafine hydrochloride treatment and an increase in sperm DNA fragmentation, while sperm parameters were not significantly affected. This effect increases with prolonged abstinence, which suggests an action in the transit of the epididymis. The use of this drug 
could cause problems in male fertility, the biomolecular mechanisms being unknown for the time being, which suggests that more studies need to be conducted in this field.

\section{CONFLICT OF INTEREST}

The authors have no conflict of interest to declare.

\section{Corresponding author:}

Andressa Moreira Giusti

Universidade do Vale do Itajaí,

Itajaí - Brazil

E-mail: andressagiusti@outlook.com

\section{REFERENCES}

Abdelbaki SA, Sabry JH, Al-Adl AM, Sabry HH. The impact of coexisting sperm DNA fragmentation and seminal oxidative stress on the outcome of varicocelectomy in infertile patients: A prospective controlled study. Arab J Urol. 2017;15:131-9. PMID: 29071142 DOI: 10.1016/j.aju.2017.03.002

AbdelSamie SM, Kamel AO, Sammour OA, Ibrahim SM. Terbinafine hydrochloride nanovesicular gel: In vitro characterization, ex vivo permeation and clinical investigation. Eur J Pharm Sci. 2016;88:91-100. PMID: 27072432 DOI: 10.1016/j.ejps.2016.04.004

Chohan KR, Griffin JT, Lafromboise M, De Jonge CJ, Carrell DT. Comparison of chromatin assays for DNA fragmentation evaluation in human sperm. J Androl. 2006;27:53-9. PMID: 16400078 DOI: $10.2164 /$ jandrol.05068

Cicaré J, Avila A, Caille A, Munuce MJ. Incorporation of the sperm chromatin dispersion test into the andrological laboratory. Rev Int Androl. 2016;14:137-43. DOI: 10.1016/j. androl.2016.04.001

Comar VA, Petersen CG, Mauri AL, Mattila M, Vagnini LD, Renzi A, Petersen B, Nicoletti A, Dieamant F, Oliveira JBA, Baruffi RLR, Franco JG Jr. Influence of the abstinence period on human sperm quality: analysis of 2,458 semen samples. JBRA Assist Reprod. 2017;21:306-12. PMID: 28985041 DOI: $10.5935 / 1518-0557.20170052$

Cooper TG, Noonan E, von Eckardstein S, Auger J, Baker HW, Behre HM, Haugen TB, Kruger T, Wang C, Mbizvo MT, Vogelsong KM. World Health Organization reference values for human semen characteristics. Hum Reprod Update. 2010;16:231-45. PMID: 19934213 DOI: 10.1093/ humupd/dmp048

Evenson DP. The Sperm Chromatin Structure Assay $\left(\operatorname{SCSA}\left({ }^{\circledR}\right)\right)$ and other sperm DNA fragmentation tests for evaluation of sperm nuclear DNA integrity as related to fertility. Anim Reprod Sci. 2016;169:56-75. PMID: 26919909 DOI: $10.1016 /$ j.anireprosci.2016.01.017

Fernández JL, Muriel L, Rivero MT, Goyanes V, Vazquez R, Alvarez JG. The sperm chromatin dispersion test: a simple method for the determination of sperm DNA fragmentation. J Androl. 2003;24:59-66. PMID: 12514084 DOI: 10.1002/j.1939-4640.2003.tb02641.x

Fernández JL, Muriel L, Goyanes V, Segrelles E, Gosálvez J, Enciso M, LaFromboise M, De Jonge C. Halosperm is an easy, available, and cost-effective alternative for determining sperm DNA fragmentation. Fertil Steril. 2005;84:860. PMID: 16213835 DOI: 10.1016/j.fertnstert.2005.05.013
Gosálvez J, González-Martínez M, López-Fernández C, Fernández JL, Sánchez-Martín P. Shorter abstinence decreases sperm deoxyribonucleic acid fragmentation in ejaculate. Fertil Steril. 2011;96:1083-6. PMID: 21924714 DOI: $10.1016 /$ j.fertnstert.2011.08.027

Gosálvez J, Caballero P, López-Fernández C, Ortega L, Guijarro JA, Fernández JL, Johnston SD, Nuñez-Calonge R. Can DNA fragmentation of neat or swim-up spermatozoa be used to predict pregnancy following ICSI of fertile oocyte donors? Asian J Androl. 2013;15:812-8. PMID: 24121979 DOI: $10.1038 / a j a .2013 .74$

Guzick DS, Overstreet JW, Factor-Litvak P, Brazil CK, Nakajima ST, Coutifaris C, Carson SA, Cisneros P, Steinkampf MP, Hill JA, Xu D, Vogel DL; National Cooperative Reproductive Medicine Network. Sperm morphology, motility, and concentration in fertile and infertile men. N Engl J Med. 2001;345:1388-93. PMID: 11794171 DOI: $10.1056 / N E J-$ Moa003005

Hamdi S, Bendayan M, Huyghe E, Soufir JC, Amar E, El Osta R, Plotton I, Delalande C, Perrin J, Leroy C, Bouker A, Pons $H$, Lejeune $H$, Robin G, Boitrelle F. COVID-19 and andrology: Recommendations of the French-speaking society of andrology (Société d'Andrologie de langue Française SALF). Basic Clin Androl. 2020;30:10. PMID: 32685170 DOI: $10.1186 /$ s12610-020-00106-4

Kanakapura B, Penmatsa VK. Analytical methods for determination of terbinafine hydrochloride in pharmaceuticals and biological materials. J Pharm Anal. 2016;6:137-49. PMID: 29403974 DOI: 10.1016/j.jpha.2016.01.003

Khan S, Jan MH, Kumar D, Telang AG. Firpronil induced spermotoxicity is associated with oxidative stress, DNA damage and apoptosis in male rats. Pestic Biochem Physiol. 2015;124:8-14. PMID: 26453224 DOI: $10.1016 / \mathrm{j}$. pestbp.2015.03.010

Kuminek G, Rauber GS, Riekes MK, de Campos CE, Monti GA, Bortoluzzi AJ, Cuffini SL, Cardoso SG. Single crystal structure, solid state characterization and dissolution rate of terbinafine hydrochloride. J Pharm Biomed Anal. 2013;78-79:105-11. PMID: 23474809 DOI: 10.1016/j. jpba.2013.02.001

Loft S, Poulsen HE. Cancer risk and oxidative DNA damage in man. J Mol Med (Berl). 1996;74:297-312. PMID: 8862511 DOI: $10.1007 /$ BF00207507

McQueen DB, Zhang J, Robins JC. Sperm DNA fragmentation and recurrent pregnancy loss: a systematic review and meta-analysis. Fertil Steril. 2019;112:5460.e3. PMID: 31056315 DOI: $10.1016 /$ j.fertnstert.2019.03.003

Millsop JW, Heller MM, Eliason MJ, Murase JE. Dermatological medication effects on male fertility. Dermatol Ther. 2013;26:337-46. PMID: 23914891 DOI: 10.1111/ dth. 12069

Nashan D, Knuth UA, Weidinger G, Nieschlag EA. The antimycotic drug terbinafine in contrast to ketoconazole lacks acute effects on the pituitary-testicular function of healthy men: a placebo-controlled double-blind trial. Acta Endocrinol (Copenh). 1989;120:677-81. PMID: 2499150 DOI: 10.1530/acta.0.1200677 
Nguyen-Powanda $P$, Robaire B. Oxidative Stress and Reproductive Function in the Aging Male. Biology (Basel). 2020;9:282. PMID: 32932761 DOI: 10.3390/biology 9090282

Okada FK, Andretta RR, Spaine DM. One day is better than four days of ejaculatory abstinence for sperm function. Reprod Fertil. 2020;1:1-10. DOI: 10.1530/RAF-20-0018

Pasqualotto FF. Investigation and assisted reproduction in the treatment of male infertility. Rev Bras Ginecol Obstet. 2007;29:103-12. DOI: 10.1590/S010072032007000200008

Pasqualotto FF, Lucon AM, de Góes PM, Sobreiro BP, Hallak J, Pasqualotto EB, Arap S. Semen profile, testicular volume, and hormonal levels in infertile patients with varicoceles compared with fertile men with and without varicoceles. Fertil Steril. 2005;83:74-7. PMID: 15652890 DOI: 10.1016/j.fertnstert.2004.06.047

Petranyi G, Ryder NS, Stütz A. Allylamine derivatives: new class of synthetic antifungal agents inhibiting fungal squalene epoxidase. Science. 1984;224:1239-41. PMID: 6547247 DOI: $10.1126 /$ science. 6547247

Potts JM, Pasqualotto FF. Seminal oxidative stress in patients with chronic prostatitis. Andrologia. 2003;35:3048. PMID: 14535860 DOI: 10.1111/j.1439-0272.2003. tb00862.x

Practice Committee of the American Society for Reproductive Medicine. The clinical utility of sperm DNA integrity testing: a guideline. Fertil Steril. 2013;99:673-7. PMID: 23391408 DOI: 10.1016/j.fertnstert.2012.12.049

Rao M, Zhao XL, Yang J, Hu SF, Lei H, Xia W, Zhu CH. Effect of transient scrotal hyperthermia on sperm parameters, seminal plasma biochemical markers, and oxidative stress in men. Asian J Androl. 2015;17:668-75. PMID: 25652627 DOI: $10.4103 / 1008-682 X .146967$

Rex AS, Aagaard J, Fedder J. DNA fragmentation in spermatozoa: a historical review. Andrology. 2017;5:622-30. PMID: 28718529 DOI: 10.1111/andr.12381

Ribas-Maynou J, García-Peiró A, Fernández-Encinas A, Abad C, Amengual MJ, Prada E, Navarro J, Benet J. Comprehensive analysis of sperm DNA fragmentation by five different assays: TUNEL assay, SCSA, SCD test and alkaline and neutral Comet assay. Andrology. 2013;1:715-22. PMID: 23843251 DOI: 10.1111/j.2047-2927.2013.00111.x

Sakkas D, Alvarez JG. Sperm DNA fragmentation: mechanisms of origin, impact on reproductive outcome, and analysis. Fertil Steril. 2010;93:1027-36. PMID: 20080235 DOI: $10.1016 /$ j.fertnstert.2009.10.046
Semet M, Paci M, Saïas-Magnan J, Metzler-Guillemain C, Boissier $R$, Lejeune $H$, Perrin $J$. The impact of drugs on male fertility: a review. Andrology. 2017;5:640-63. PMID: 28622464 DOI: $10.1111 /$ andr. 12366

Shekarriz M, Sharma RK, Thomas AJ Jr, Agarwal A. Positive myeloperoxidase staining (Endtz test) as an indicator of excessive reactive oxygen species formation in semen. J Assist Reprod Genet. 1995;12:70-4. PMID: 7545483 DOI: 10.1007/BF02211372

Stedile R. Reproductive toxicity study of $\beta$-glucan and itraconazole association in wistar rats [Doctoral dissertation thesis]. Porto Alegre: Federal University of Rio Grande do Sul; 2014. Available at: http://hdl.handle.net/10183/94756

Stütz A, Petranyi G. Synthesis and antifungal activity of (E)$\mathrm{N}$-(6,6-dimethyl-2-hepten-4-ynyl)-N-methyl-1-naphtha lenemethanamine (SF 86-327) and related allylamine derivatives with enhanced oral activity. J Med Chem. 1984;27:1539-43. PMID: 6502589 DOI: 10.1021/jm00378a003

Vandekerckhove FW, De Croo I, Gerris J, Vanden Abbeel E, De Sutter P. Sperm Chromatin Dispersion Test before Sperm Preparation Is Predictive of Clinical Pregnancy in Cases of Unexplained Infertility Treated with Intrauterine Insemination and Induction with Clomiphene Citrate. Front Med. 2016;3:63. PMID: 27933295 DOI: 10.3389/fmed.2016.00063

Wright C, Milne S, Leeson H. Sperm DNA damage caused by oxidative stress: modifiable clinical, lifestyle and nutritional factors in male infertility. Reprod Biomed Online. 2014; 28:684703. PMID: 24745838 DOI: $10.1016 /$ j.rbmo.2014.02.004

WHO - World Health Organization. WHO Laboratory Manual for the Examination and Processing of Human Semen. 5th ed. Geneva: WHO Press; 2010.

WHO - World Health Organization. WHO model list of essential medicines (21st List). Geneva: WHO; 2019. Available at: http://www.who.int/medicines/publications/essentialmedicines/en

Zamkowska D, Karwacka A, Jurewicz J, Radwan M. Environmental exposure to non-persistent endocrine disrupting chemicals and semen quality: An overview of the current epidemiological evidence. Int J Occup Med Environ Health. 2018;31:377-414. PMID: 30160090 DOI: 10.13075/ijomeh.1896.01195

Zhang Z, Zhu L, Jiang $\mathrm{H}$, Chen $\mathrm{H}$, Chen $\mathrm{Y}$, Dai Y. Sperm DNA fragmentation index and pregnancy outcome after IVF or ICSI: a meta-analysis. J Assist Reprod Genet. 2015;32:1726. PMID: 25392073 DOI: $10.1007 /$ s10815-014-0374-1

Zini A, Libman J. Sperm DNA damage: importance in the era of assisted reproduction. Curr Opin Urol. 2006;16:428-34. PMID: 17053523 DOI: $10.1097 / 01$. mou.0000250283.75484.dd 